\title{
Electrospray Ionization Mass Spectrometry Screening of Piperidine Alkaloids from Senna spectabilis (Fabaceae) Extracts: Fast Identification of New Constituents and Co-metabolites
}

\author{
Marcos Pivatto ${ }^{a}$, Antônio E. M. Crotti ${ }^{b}$, Norberto P. Lopes ${ }^{c}$, Ian Castro-Gamboa ${ }^{a}$, Amanda de Rezende $^{a}$, \\ Cláudio Viegas Jr. ${ }^{a}$, Maria Claudia M. Young ${ }^{d}$, Maysa Furlan ${ }^{a}$ and Vanderlan S. Bolzani ${ }^{*, a}$ \\ ${ }^{a}$ Instituto de Química, Universidade Estadual Paulista, CP 355, 14801-970 Araraquara - SP, Brazil \\ ${ }^{b}$ Núcleo de Pesquisas em Ciências Exatas e Tecnológicas, Universidade de Franca, Av. Dr. Armando Salles \\ de Oliveira 201, 14404-600 Franca - SP, Brazil \\ ${ }^{c}$ Departamento de Física e Química, Faculdade de Ciências Farmacêuticas, Universidade de São Paulo,
} Via do Café s/n, 14040-903 Ribeirão Preto - SP, Brazil

${ }^{d}$ Seção de Fisiologia e Bioquímica de Plantas, Instituto de Botânica, CP 4005, 01061-970 São Paulo - SP, Brazil

\begin{abstract}
O padrão de fragmentação de uma série homóloga de alcalóides piperidínicos isolados de Senna spectabilis foi investigado utilizando-se espectrometria de massas tandem com ionização por electrospray (ESI-EM/EM). A análise dos extratos EtOH e frações das flores e dos frutos de $S$. spectabilis por ESI-EM e ESI-EM/EM permitiu elucidar a estrutura de quatro componentes pertencentes a uma série homóloga destes alcalóides, bem como de quatro co-metabólitos inéditos. A elucidação estrutural dos co-metabólitos, com base no padrão de fragmentação de alcalóides piperidínicos previamente isolados, e confirmados pelos dados de EM de alta resolução, demonstra a importância desta técnica para a determinação do "perfil metabolômico" de uma espécie de importância farmacológica.
\end{abstract}

The fragmentation pattern of a homologous series of piperidine alkaloids isolated from $S$. spectabilis was investigated using electrospray ionization tandem mass spectrometry (ESI-MS/ MS). The ESI-MS and ESI-MS/MS analyses of EtOH extracts and fractions from flowers and fruits of $S$. spectabilis allowed to elucidate the structures of four new compounds. The identification of these co-metabolites, based on the fragmentation patterns of previously isolated compounds, and further confirmed by accurate mass spectrometry defines this technique as a powerful tool to determine the "metabolomic profile" of species which has pharmacological importance.

Keywords: Senna spectabilis, piperidine alkaloids, metabolomic profile, electrospray, tandem mass spectrometry

\section{Introduction}

Senna spectabilis (synonym of Cassia spectabilis) is an arborous species of Fabaceae (subfamily Caesalpiniaceae). In Brazil, many species of both Cassia and Senna are used as ornamental plants due to their beautiful flowers. Some species of are also commonly used in Africa and Asia countries, mainly in India and China, as traditional medicine formulations for treatment of several diseases, alternatively to the conventional allopathic medicine. ${ }^{1,2}$ Phenolic compounds have been proposed to be responsible for several

* e-mail: bolzaniv@iq.unesp.br pharmacological properties attributed to these species, such as anti-inflammatory, analgesic, laxative, antimicrobial and antiulceral. ${ }^{3}$ Recently, leaves and flowers of S. spectabilis were reported to be valuable sources of bioactive piperidine alkaloids (Figure 1). Recently the cytotoxicity of these metabolites was reported using mutant strains of Saccharomyces cerevisiae, which is indicative of their potential antitumoral activity. ${ }^{3}$ Interestingly, further assays with these alkaloids demonstrated significant antinociceptive activity, and also revealed them as acetylcholinesterase inhibitors. ${ }^{4,5}$ Also, it was attributed to piperidine alkaloids, purgative, ${ }^{6,7}$ and antimicrobial ${ }^{8}$ activities, as well as the ability for specific inhibition of superoxide macrofages. ${ }^{9}$ Considering 


\begin{tabular}{lcccccc} 
& & & \\
& $\mathrm{R}^{1}$ & $\mathrm{R}^{2}$ & $\mathrm{R}^{3}$ & $n$ & $\mathrm{MW}$ & Configuration \\
\hline $\mathbf{1}$ & $\mathrm{H}$ & $\mathrm{H}$ & $-\mathrm{COCH}_{3}$ & 8 & 297 & Not assigned \\
$\mathbf{2}$ & $\mathrm{H}$ & $\mathrm{H}$ & $-\mathrm{COCH}_{3}$ & 10 & 325 & $2 R, 3 R, 6 \mathrm{~S}$ \\
$\mathbf{3}$ & $\mathrm{H}$ & $\mathrm{H}$ & $-\mathrm{COCH}_{3}$ & 10 & 325 & $2 R, 3 R, 6 R$ \\
$\mathbf{4}$ & $\mathrm{OH}$ & $\mathrm{H}$ & $-\mathrm{COCH}_{3}$ & 8 & 313 & Not assigned \\
$\mathbf{5}$ & $\mathrm{OH}$ & $\mathrm{H}$ & $-\mathrm{COCH}_{3}$ & 10 & 341 & $2 R, 3 R, 6 \mathrm{~S}$ \\
$\mathbf{6}$ & $\mathrm{H}$ & $-\mathrm{COCH}$ & $-\mathrm{COCH}_{3}$ & 8 & 339 & Not assigned \\
$\mathbf{7}$ & $\mathrm{H}$ & $-\mathrm{COCH}$ & $-\mathrm{COCH}_{3}$ & 10 & 367 & $2 R, 3 R, 6 \mathrm{~S}$ \\
$\mathbf{8}$ & $\mathrm{H}$ & $\mathrm{H}$ & $-\mathrm{CH}_{3}\left(\mathrm{OH}_{3} \mathrm{CH}_{3}\right.$ & 8 & 299 & Not assigned \\
$\mathbf{9}$ & $\mathrm{H}$ & $\mathrm{H}$ & $\mathrm{CH}^{2}\left(\mathrm{OH}_{3} \mathrm{CH}_{3}\right.$ & 10 & 327 & $2 R, 3 R, 6 \mathrm{~S}$ \\
$\mathbf{1 0}$ & $\mathrm{H}$ & $p$-coumaroyl & $-\mathrm{COCH}_{3}$ & 8 & 443 & Not assigned \\
$\mathbf{1 1}$ & $\mathrm{H}$ & $p$-coumaroyl & $-\mathrm{COCH}_{3}$ & 10 & 471 & Not assigned \\
$\mathbf{1 2}$ & $\mathrm{H}$ & feruloyl & $-\mathrm{COCH}_{3}$ & 8 & 473 & Not assigned \\
$\mathbf{1 3}$ & $\mathrm{H}$ & feruloyl & $-\mathrm{COCH}_{3}$ & 10 & 501 & Not assigned
\end{tabular}

Figure 1. Structure of alkaloids isolated from S. spectabilis.

these remarkable pharmacological properties, there is an interest in searching for further piperidine alkaloids from $S$. spectabilis, including major and minor alkaloid cometabolites. However, these alkaloids are biosynthesized by this plant species in very small amounts, and it has not been possible to obtain sufficient pure material for full structural determination using NMR techniques. Therefore, no detailed structural information for these alkaloids co-metabolites is available.

In recent years, liquid chromatography (LC) coupled to electrospray ionization mass spectrometry (ESI-MS) has been shown to be a powerful tool to separate and identify natural products. ${ }^{10-12}$ Structural elucidation of natural cometabolites in complex mixtures has also been possible by use of electrospray ionization tandem mass spectrometry (ESI-MS/MS), even from small quantities of plant material or other biological samples. ${ }^{13,14}$ The use of this technique has increased substantially nowadays, and ESI-MS/MS experiments can be useful for various studies on natural product chemistry, including biosynthesis, ${ }^{15-18}$ metabolomic profile $^{19,20}$ and dereplication. ${ }^{13,21,22}$ The isolation and characterization of several alkaloids have been reported, however, only a handful of papers describe the use of ESIMS/MS for the characterization of new natural products. ${ }^{11,23-27}$ Advances in the development of high-resolution MS and the elucidation of gas-phase fragmentation chemistry is now helping in the analysis of new compounds and new organic reactions. ${ }^{28-32}$

In this study, we report a ESI-MS/MS spectrometric method for characterization of piperidine alkaloids from flowers and fruits extracts of $S$. spectabilis. This technique is also shown to be an excellent tool for analysis of the different alkaloid isomers co-metabolites as a homologous series, which constitutes the chemical profile or "fingerprint" in whole tissues. Additionally, a simple and rapid method for differentiation and identification of known alkaloid mixtures, and also of new piperidine analogs can be useful to describe the metabolomic design from different part of this plant species.

\section{Experimental}

\section{Plant material}

The flowers and fruits of $S$. spectabilis were collected in February 2004 from a specimen cultivated at the Institute of Chemistry in Araraquara, São Paulo State, Brazil, and identified by Dr. Inês Cordeiro. A voucher specimen (SP 370.917) was deposited at the herbarium of the Botanic Garden of São Paulo, São Paulo - SP, Brazil.

\section{Extraction and sample preparation}

Green fruits and dried flowers from $S$. spectabilis $(8.0$ $\mathrm{kg}$ and $950.0 \mathrm{~g}$, respectively) were powdered and extracted $(5 \times 5 \mathrm{~L})$ with EtOH. The ethanolic extracts $(2.0 \mathrm{~g})$ of both green fruits and dried flowers were re-dissolved in $5 \%$ aqueous $\mathrm{H}_{2} \mathrm{SO}_{4}(30 \mathrm{~mL})$ and the insoluble portion was filtered off. The acid solution was extracted with hexane $(3 \times 20 \mathrm{~mL}$ ) to yield a non-alkaloidal portion (14.8 from fruits and $5.7 \mathrm{mg}$ from flowers). The residual acid solution was basified $(\mathrm{pH} 9)$ with $\mathrm{NH}_{4} \mathrm{OH}$, then extracted with $\mathrm{CH}_{2} \mathrm{Cl}_{2}(3 \times 20 \mathrm{~mL})$. The resulting extracts were dried over anhydrous $\mathrm{MgSO}_{4}$ and concentrated, furnishing a crude alkaloidal fraction from fruits $(121.6 \mathrm{mg})$ and flowers $(272.7 \mathrm{mg})$.

An aliquot of each extract was dissolved in $\mathrm{MeOH}$ to obtain a concentration of $1 \mathrm{mg} \mathrm{mL}^{-1}$ and decanted during $12 \mathrm{~h}$. The samples were filtered and clean up in a solidliquid extraction, using a Gelman's polytetrafluorethylene membrane (PTFE) of $0.45 \mu \mathrm{m}$ in diameter.

\section{Mass spectrometry}

Methanol (HPLC grade) and de-ionized water (MilliQ) was used throughout the whole study. ESI mass spectra, precursor and product ions scans were acquired in positive ion mode at unit mass resolution and recorded on a Quattro-LC spectrometer (Micromass, Manchester, UK) which held a quadrupole, hexapole quadrupole configuration. The instrumental conditions used were: probe electrospray tip voltage $3 \mathrm{kV}$; cone voltage $25 \mathrm{~V}$; nitrogen was used for both the bath and nebulizing gas flowing at $345 \mathrm{~L} \mathrm{~h}^{-1}$ and $27 \mathrm{~L} \mathrm{~h}^{-1}$, respectively. Solutions were infused 
into the ESI source at a flow-rate of $5 \mu \mathrm{L} \mathrm{min}{ }^{-1}$, using a Harvard Apparatus model 1746 (Holliston, MA). Compounds and cleaned up extracts were dissolved in $20 \%$ aqueous methanol to give a concentration of $0.5 \mathrm{mg}$ $\mathrm{mL}^{-1}$ and $10 \mu \mathrm{L}$ were injected for each analysis. The source temperature was set at $80{ }^{\circ} \mathrm{C}$.

Electrospray ionization tandem mass spectrometry (ESI-MS/MS) experiments were carried out in positive ion mode only, using the same conditions described above. The collision cell was filled with Ar gas at pressure of 7 psi and the collision energy was fixed at $25 \mathrm{eV}$ to maximize the formation of diagnostic fragments.

Accurate-mass measurements were performed on a quadrupole-time of flight instrument (UltrOTOF-Q, Bruker Daltonics, Billerica, MA).

\section{Results and Discussion}

ESI-MS/MS data of the protonated molecule 2, 3, 5 and 7 (Figure 1), which were previously isolated, ${ }^{3,5}$ are shown in Table 1. The product ion mass spectra of 2 (of $\mathrm{m} / \mathrm{z}$ 326) and 7 (of $\mathrm{m} / \mathrm{z} 368$ ), that only differ in the lateral chain linked at C-6 of the piperidine ring, are very similar. The most abundant fragment ion for both the spectra is that of $\mathrm{m} / \mathrm{z} 308$, which results from $\mathrm{H}_{2} \mathrm{O}$ loss (18 Da) or $\mathrm{CH}_{3} \mathrm{CO}_{2} \mathrm{H}$ loss $(60 \mathrm{Da})$, respectively from the precursor ion. Additionally, less abundant fragment ions at the low $\mathrm{m} / \mathrm{z}$ region, of $m / z 70,81,95$, are also of very similar abundances for 2 and 7. Similarly, the predominant process in the fragmentation of $\mathbf{5}$ (of $\mathrm{m} / \mathrm{z} 342$ ) is the loss of $\mathrm{H}_{2} \mathrm{O}$. For $\mathbf{5}$, however, further loss of $\mathrm{H}_{2} \mathrm{O}$ (from $\left[\mathrm{M}+\mathrm{H}-\mathrm{H}_{2} \mathrm{O}\right]^{+}$) forms the ion of $m / z$ 306. This difference is likely associated with the hydroxyl group at $\mathrm{C}-7$, thus allowing for the second loss of $\mathrm{H}_{2} \mathrm{O}$. In addition, the fragment ion of $\mathrm{m} / z 280$ also can be considered diagnostic for the hydroxyl substituent at C-7, and it is observed only for 5. Finally, similarities between the fragment ions of the diasteroisomers $\mathbf{2}$ and $\mathbf{3}$, of $\mathrm{m} / \mathrm{z} 326$, indicate that the configuration at C-6 has little influence on their dissociation pattern. These data demonstrate that the loss of $\mathrm{H}_{2} \mathrm{O}$ at $\mathrm{C}-3$ (for $\mathbf{2}, \mathbf{3}$ and $\mathbf{5}$ or $\mathrm{CH}_{3} \mathrm{CO}_{2} \mathrm{H}$, for 7) is the predominant process in the fragmentation of protonated piperidine alkaloids. In addition, the fragment ion $\left[\mathrm{M}+\mathrm{H}-\mathrm{R}^{2} \mathrm{OH}-\mathrm{H}_{2} \mathrm{O}\right]^{+}$, together with that of $\mathrm{m} / \mathrm{z} 280$, is considered to be also diagnostic of a hydroxyl group at C-7.

ESI-MS of crude alkaloidal fraction of flowers and fruits from S. spectabilis are shown in Figures 2 and 3, respectively. In order to investigate the structure of various alkaloid co-metabolites, a series of ions with even $\mathrm{m} / \mathrm{z}$ relative value, that are usually characteristic for protonated molecules containing odd number of nitrogens, ${ }^{32-34}$ were analyzed by ESI tandem mass spectrometry (ESI-MS/MS), as shown in Table 1 .

Loss of $\mathrm{H}_{2} \mathrm{O}$ is the predominant process in the fragmentation of the ion of $\mathrm{m} / \mathrm{z}, 298$ (1). Other minor ions are those of $m / z$ 70, 81, 95 and 109. These ESI-MS/MS data are similar to those of $\mathbf{2}$ and $\mathbf{3}$, with a $\mathrm{m} / \mathrm{z}$ shift of 28 regarded to the corresponding ions of $\mathrm{m} / \mathrm{z} 298$ and 280 (of $\mathrm{m} / \mathrm{z}, 326$ and $\mathrm{m} / \mathrm{z}, 308$, respectively). This shift is attributed to two methylenes units at the alkyl side chain at C-6.

Table 1. Main fragment ions of 1-13 (low accuracy). Relative abundances are given in parentheses

\begin{tabular}{|c|c|c|c|c|c|c|c|c|c|c|c|c|c|}
\hline & 1 & 2 & 3 & 4 & 5 & 6 & 7 & 8 & 9 & 10 & 11 & 12 & 13 \\
\hline $\mathrm{A}[\mathrm{M}+\mathrm{H}]^{+}$ & $\begin{array}{l}298 \\
(10)\end{array}$ & $\begin{array}{l}326 \\
(10)\end{array}$ & $\begin{array}{l}326 \\
(18)\end{array}$ & $\begin{array}{l}314 \\
(20)\end{array}$ & $\begin{array}{l}342 \\
(30)\end{array}$ & $\begin{array}{c}340 \\
(8)\end{array}$ & $\begin{array}{l}368 \\
(20)\end{array}$ & $\begin{array}{l}300 \\
(25)\end{array}$ & $\begin{array}{l}328 \\
(30)\end{array}$ & $\begin{array}{l}444 \\
(10)\end{array}$ & $\begin{array}{l}472 \\
(15)\end{array}$ & $\begin{array}{l}474 \\
(10)\end{array}$ & $\begin{array}{l}502 \\
(17)\end{array}$ \\
\hline $\mathrm{B}\left(\mathrm{A}-\mathrm{R}^{2} \mathrm{H}\right)$ & & & & & & & & & & $\begin{array}{l}298 \\
(30)\end{array}$ & $\begin{array}{l}326 \\
(30)\end{array}$ & $\begin{array}{l}298 \\
(32)\end{array}$ & $\begin{array}{l}326 \\
(40)\end{array}$ \\
\hline $\mathrm{C}\left(\mathrm{A}-\mathrm{R}^{2} \mathrm{OH} / \mathrm{B}-\mathrm{H}_{2} \mathrm{O}\right)$ & $\begin{array}{c}280 \\
(100)\end{array}$ & $\begin{array}{l}308 \\
(100)\end{array}$ & $\begin{array}{l}308 \\
(100)\end{array}$ & $\begin{array}{l}296 \\
(100)\end{array}$ & $\begin{array}{c}324 \\
(100)\end{array}$ & $\begin{array}{c}280 \\
(100)\end{array}$ & $\begin{array}{l}308 \\
(100)\end{array}$ & $\begin{array}{c}282 \\
(100)\end{array}$ & $\begin{array}{l}310 \\
(100)\end{array}$ & $\begin{array}{l}280 \\
(100)\end{array}$ & $\begin{array}{l}308 \\
(100)\end{array}$ & $\begin{array}{l}280 \\
(90)\end{array}$ & $\begin{array}{c}308 \\
(100)\end{array}$ \\
\hline $\mathrm{D}\left(\mathrm{C}-\mathrm{H}_{2} \mathrm{O}\right)$ & & & & $\begin{array}{l}278 \\
(60)\end{array}$ & $\begin{array}{l}306 \\
(85)\end{array}$ & & & $\begin{array}{l}264 \\
(60)\end{array}$ & $\begin{array}{l}292 \\
(50)\end{array}$ & & & & \\
\hline $\mathrm{E}\left(\left[\mathrm{R}^{2}\right]^{+}\right)$ & & & & & & & & & & $\begin{array}{l}147 \\
(80)\end{array}$ & $\begin{array}{l}147 \\
(50)\end{array}$ & $\begin{array}{l}177 \\
(100)\end{array}$ & $\begin{array}{l}177 \\
(90)\end{array}$ \\
\hline Not assigned & & & & $\begin{array}{l}252 \\
(20)\end{array}$ & $\begin{array}{l}280 \\
(20)\end{array}$ & & & & & & & & \\
\hline $\mathrm{F}\left(\mathrm{E}-\mathrm{CH}_{3} \mathrm{OH}\right)$ & & & & & & & & & & & & $\begin{array}{l}145 \\
(17)\end{array}$ & $\begin{array}{l}145 \\
(10)\end{array}$ \\
\hline Not assigned & $\begin{array}{l}109 \\
(10)\end{array}$ & $\begin{array}{l}109 \\
(8)\end{array}$ & $\begin{array}{l}109 \\
(5)\end{array}$ & $\begin{array}{l}109 \\
(5)\end{array}$ & $\begin{array}{l}109 \\
(3)\end{array}$ & $\begin{array}{l}109 \\
(2)\end{array}$ & $\begin{array}{l}109 \\
(3)\end{array}$ & $\begin{array}{l}109 \\
(8)\end{array}$ & $\begin{array}{l}109 \\
(3)\end{array}$ & $\begin{array}{l}109 \\
(<1)\end{array}$ & $\begin{array}{l}109 \\
(<1)\end{array}$ & $\begin{array}{l}109 \\
(<1)\end{array}$ & $\begin{array}{l}109 \\
(<1)\end{array}$ \\
\hline Not assigned & $\begin{array}{l}95 \\
(15)\end{array}$ & $\begin{array}{l}95 \\
(12)\end{array}$ & $\begin{array}{l}95 \\
(7)\end{array}$ & $\begin{array}{c}95 \\
(10)\end{array}$ & $\begin{array}{l}95 \\
(5)\end{array}$ & $\begin{array}{l}95 \\
(6)\end{array}$ & $\begin{array}{c}95 \\
(10)\end{array}$ & $\begin{array}{c}95 \\
(15)\end{array}$ & $\begin{array}{l}95 \\
(5)\end{array}$ & $\begin{array}{c}95 \\
(<1)\end{array}$ & $\begin{array}{c}95 \\
(<1)\end{array}$ & $\begin{array}{c}95 \\
(<1)\end{array}$ & $\begin{array}{c}95 \\
(<1)\end{array}$ \\
\hline Not assigned & $\begin{array}{c}81 \\
(15)\end{array}$ & $\begin{array}{c}81 \\
(10)\end{array}$ & $\begin{array}{l}81 \\
(7)\end{array}$ & $\begin{array}{c}81 \\
(10)\end{array}$ & $\begin{array}{l}81 \\
(5)\end{array}$ & $\begin{array}{l}81 \\
(4)\end{array}$ & $\begin{array}{l}81 \\
(5)\end{array}$ & $\begin{array}{c}81 \\
(14)\end{array}$ & $\begin{array}{l}81 \\
(5)\end{array}$ & $\begin{array}{c}81 \\
(<1)\end{array}$ & $\begin{array}{c}81 \\
(<1)\end{array}$ & $\begin{array}{c}81 \\
(<1)\end{array}$ & $\begin{array}{c}81 \\
(<1)\end{array}$ \\
\hline Not assigned & $\begin{array}{c}70 \\
(35)\end{array}$ & $\begin{array}{c}70 \\
(30)\end{array}$ & $\begin{array}{c}70 \\
\text { (13) }\end{array}$ & $\begin{array}{l}70 \\
(5)\end{array}$ & $\begin{array}{c}70 \\
(10)\end{array}$ & $\begin{array}{c}70 \\
(10)\end{array}$ & $\begin{array}{c}70 \\
(20)\end{array}$ & $\begin{array}{c}70 \\
(30)\end{array}$ & $\begin{array}{c}70 \\
(12)\end{array}$ & $\begin{array}{c}70 \\
(<1)\end{array}$ & $\begin{array}{l}70 \\
\text { (3) }\end{array}$ & $\begin{array}{c}70 \\
(<1)\end{array}$ & $\begin{array}{l}70 \\
(<1)\end{array}$ \\
\hline
\end{tabular}




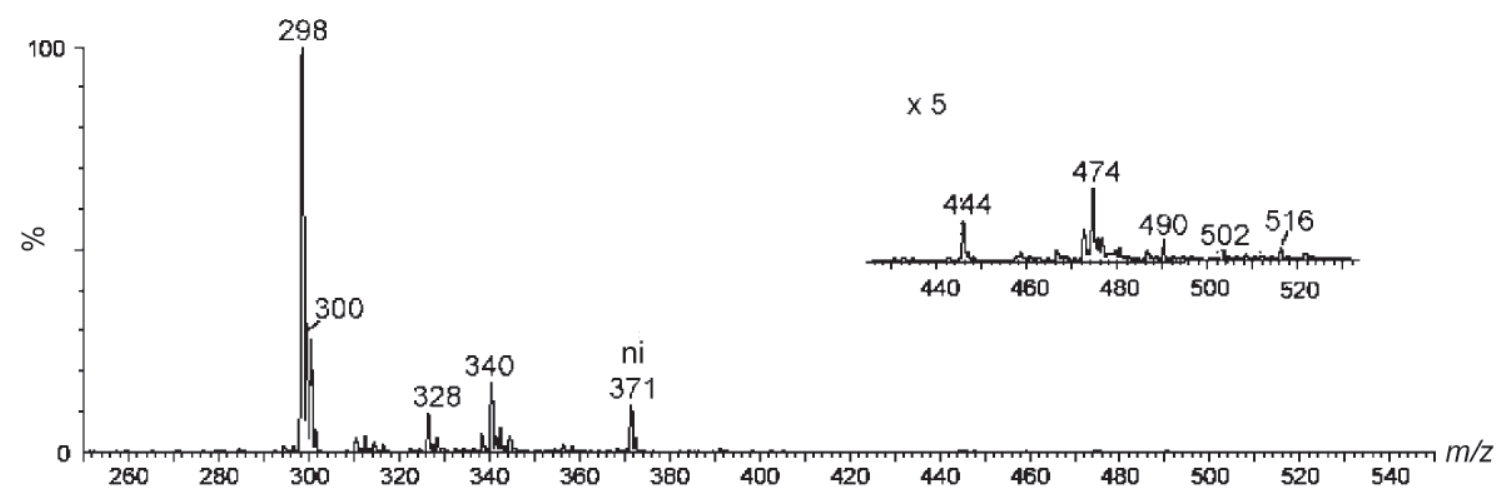

Figure 2. ESI-MS of the alkaloidal crude methanolic extract from the flowers of S. spectabilis. (ni = not idendified).

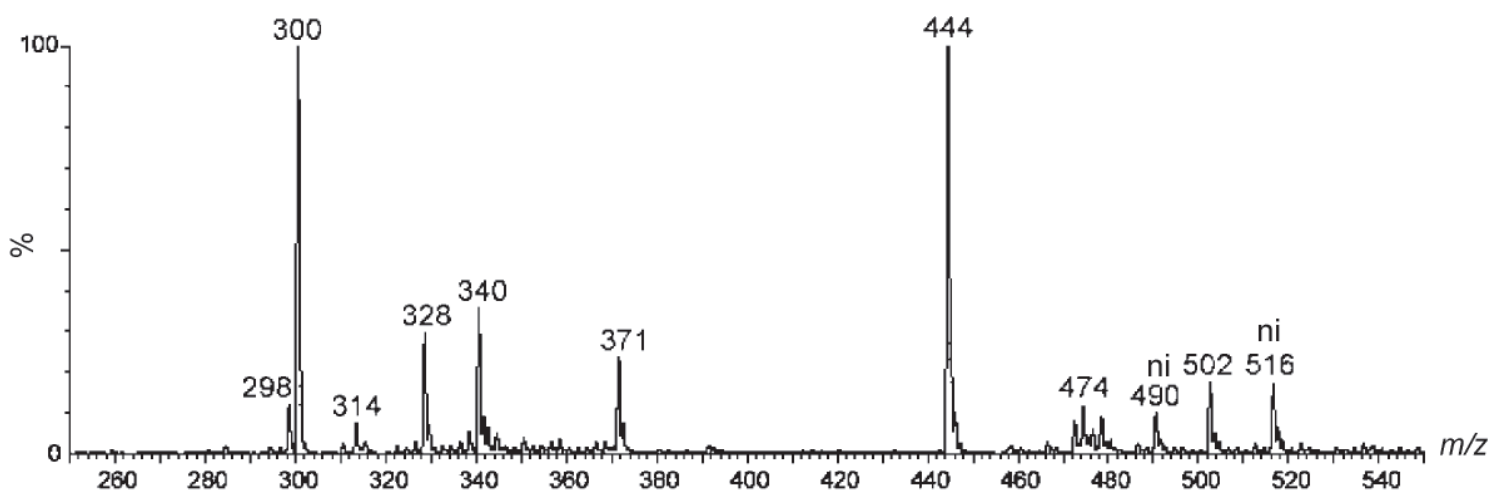

Figure 3. ESI-MS of the alkaloidal crude methanolic extract from the fruits of S. spectabilis. $($ ni $=$ not idendified).

Therefore, $\mathbf{1}$ is expected to be homologue of $\mathbf{2}$ and $\mathbf{3}$ differing only in the number of $\mathrm{CH}_{2}$ units of the substituent at $\mathrm{C}-6(\mathrm{n}=8$ for $\mathbf{1} ; \mathrm{n}=10$ for $\mathbf{2}$ and $\mathbf{3})$. A similar alkaloid was previously isolated from Cassia excelsa. ${ }^{35}$ However, the configuration of the stereocenters of the alkaloid core (C-2, C-3, and C-6) could not be unambiguously assigned as their influences on the fragmentation processes were not evident in this study.

The second most abundant fragment ion of $\mathbf{6}$, of $\mathrm{m} / \mathrm{z}$ 280 , is resulting of loss of $\mathrm{CH}_{3} \mathrm{CO}_{2} \mathrm{H}(60 \mathrm{Da})$, as compared to 7. Further similarities between the ESI-MS/MS data of 6 and 7 (i.e., the low mass fragment ions series at $\mathrm{m} / \mathrm{z} 70$, 81,95 and 109), that differ by $28 \mathrm{~m} / z$ units, are indicative of the lack of two methylene units for $\mathbf{6}$, as compared to $\mathbf{7}$ (Table 1). It appears to be no previous reports on this compound or on its diasteroisomers. In the same manner, ESI-MS/MS of the ion of $\mathrm{m} / \mathrm{z} 314$ (4) shows fragment ions of $\mathrm{m} / \mathrm{z}, 296$ (loss of $\mathrm{H}_{2} \mathrm{O}$ ) and $\mathrm{m} / z, 278$ (loss of two $\mathrm{H}_{2} \mathrm{O}$ molecules) with a mass shift of 28 as for $\mathbf{5}$ (of $\mathrm{m} / \mathrm{z}$ 324 and $\mathrm{m} / \mathrm{z}, 306$, respectively). These data indicated that 4 is a $\left(\mathrm{CH}_{2}\right)_{8}$ homologue of 5 (Figure 1), previously isolated from Cassia leptophylla. ${ }^{5}$
The two major fragment ions in the ESI-MS/MS spectrum of $\mathrm{m} / \mathrm{z} 328(\mathbf{9})$, of $\mathrm{m} / \mathrm{z} 310$ and $\mathrm{m} / \mathrm{z}, 292$, result from two consecutive losses of $\mathrm{H}_{2} \mathrm{O}$ (Table 1). In principle, they could be indicative of a hydroxyl substituent at C-7, similar to $\mathbf{5}$. However, for $\mathbf{9}$ the lack of the fragment ion of $\mathrm{m} / \mathrm{z} 280$ (which is diagnostic for the hydroxyl substituent at C-7), as well as the two $\mathrm{m} / \mathrm{z}$ shift units from the corresponding ion of $\mathbf{3}$, are strong evidences for a hydroxyl group bounded in another position of the alkaloid skeleton, most probably formed by the reduction of the carbonyl group on the side chain linked at C-6. This data suggests that 9 is similar to an alkaloid previously isolated from Cassia spectabilis. ${ }^{5}$ Finally, comparison between the ESIMS/MS of 8 (of $\mathrm{m} / \mathrm{z} 300$ ) and $\mathbf{9}$ (of $\mathrm{m} / \mathrm{z}, 328$ ), that also displays a $\mathrm{m} / \mathrm{z}$ shift of 28 , suggests that $\mathbf{8}$ exhibits an alkyl side chain with $n=8$ instead of $n=10$ (for 9). Such compound $(\mathbf{8})$ has been previously isolated from $C$. spectabilis. 3.5

The fragment ion of $m / z, 280$ in the ESI-MS/MS of $\mathbf{1 0}$ $\left(\mathrm{m} / z\right.$ 444) results from the loss of a $164 \mathrm{Da}$, likely $\mathrm{R}^{2} \mathrm{OH}$ (Table 1). An analogous fragment ion is also observed in the spectra of $\mathbf{1}$ and $\mathbf{6}(n=8)$. However, for $\mathbf{1 0}$ the ion of 
$\mathrm{m} / \mathrm{z} 280$ can also be formed by loss of $\mathrm{H}_{2} \mathrm{O}$. In addition, the relative abundance of the fragment ion of $\mathrm{m} / \mathrm{z} 147$ (that was expected to be diagnostic for the $\mathrm{R}^{2}$ substituent group at C-3), is higher than those of the low mass fragment ions series of $m / z, 70,81,95$ and 109 , whose intensity is much lower than that of their corresponding ions in the spectra of 1-9, thus suggesting a phenylpropanoid moiety linked at C-3. The fragment ions of $m / z 147$ and $\left([\mathrm{M}+\mathrm{H}-146]^{+}\right.$has been recently used to characterize a $p$-coumaroyl substituent (Figure 1). ${ }^{35}$ The fragment ion of $\mathrm{m} / \mathrm{z}, 147$ is considered to result from charge-induced fragmentation that forms an acylium ion E (pathway III, Scheme 1). This process could be initiated by proton shift from the amine group to the carbonyl of the ester group. ${ }^{36}$ In contrast, loss of $p$-coumaric acid (pathway II), as well as the formation of the fragment ion

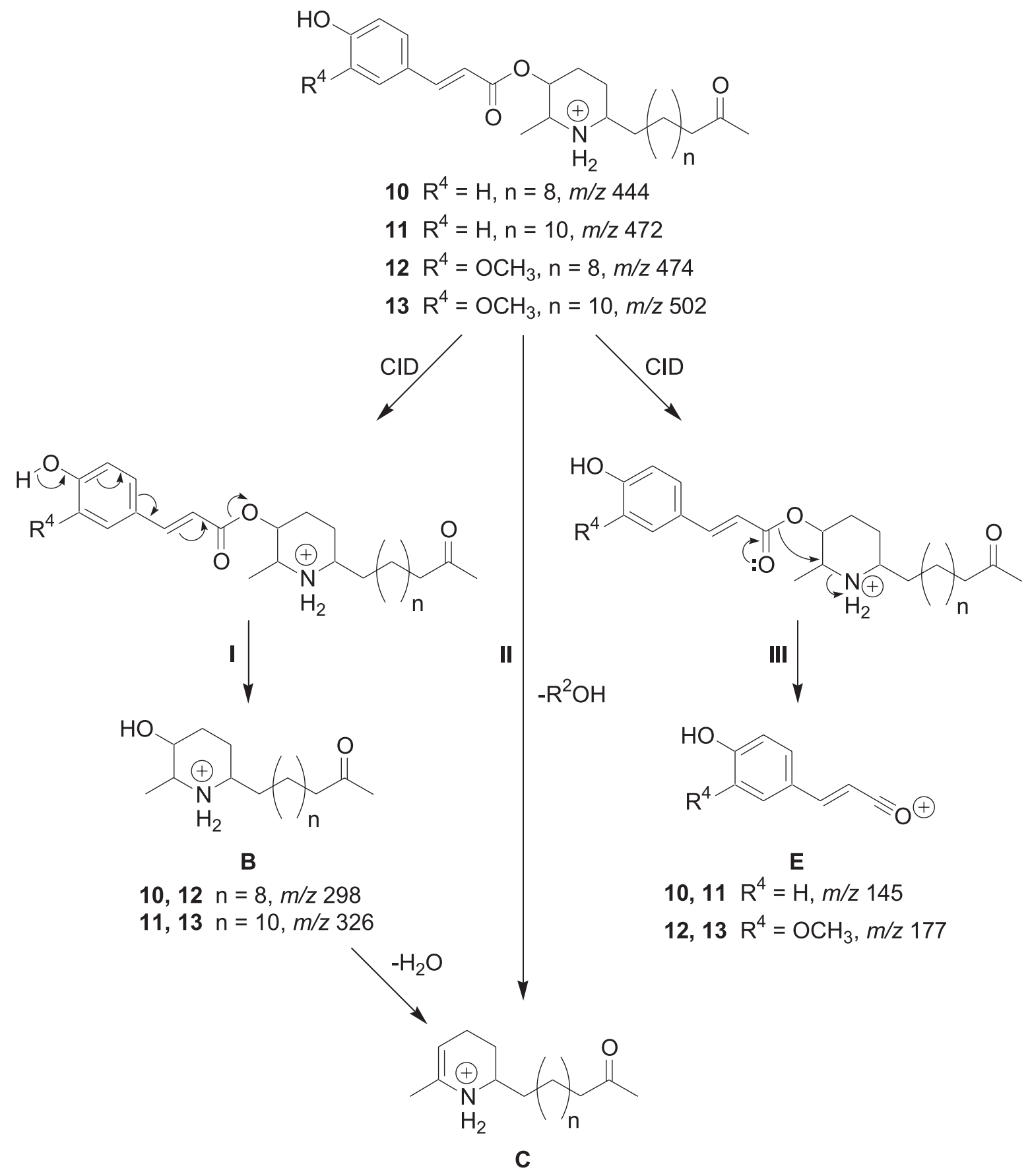

10, $12 \mathrm{n}=8, \mathrm{~m} / \mathrm{z} 280$

11, $13 \mathrm{n}=10, \mathrm{~m} / \mathrm{z} 308$

Scheme 1. Proposed fragmentation for 10-13. 


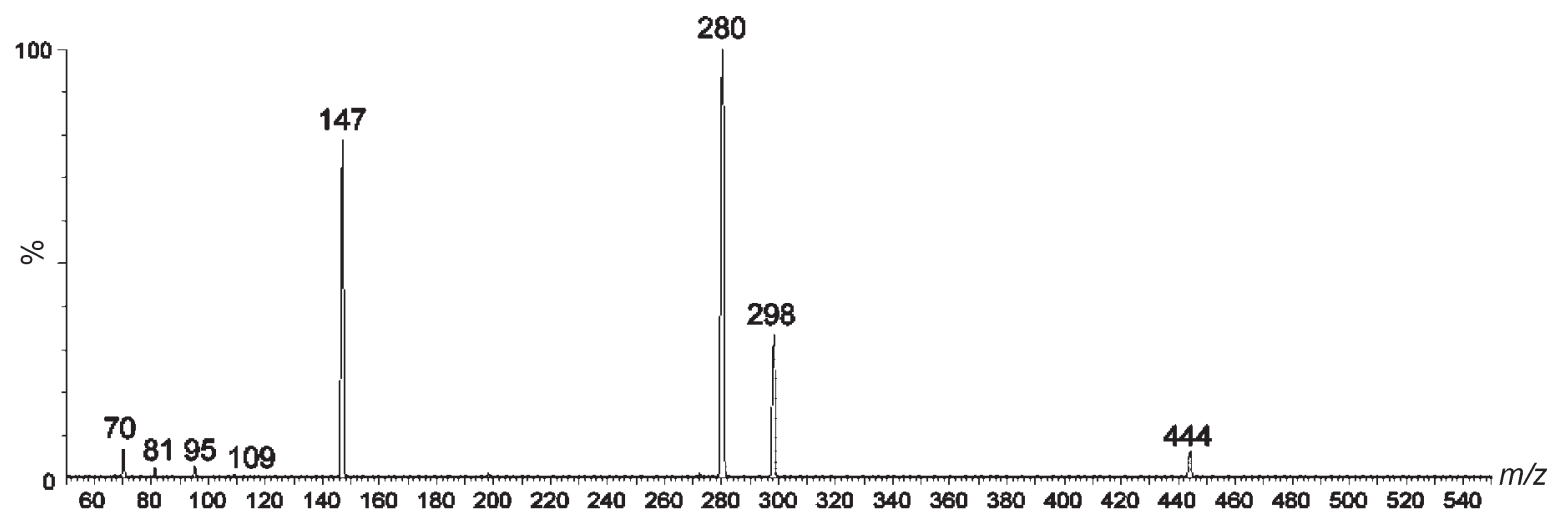

Figure 4. ESI-MS/MS of $\mathbf{1 0}$.

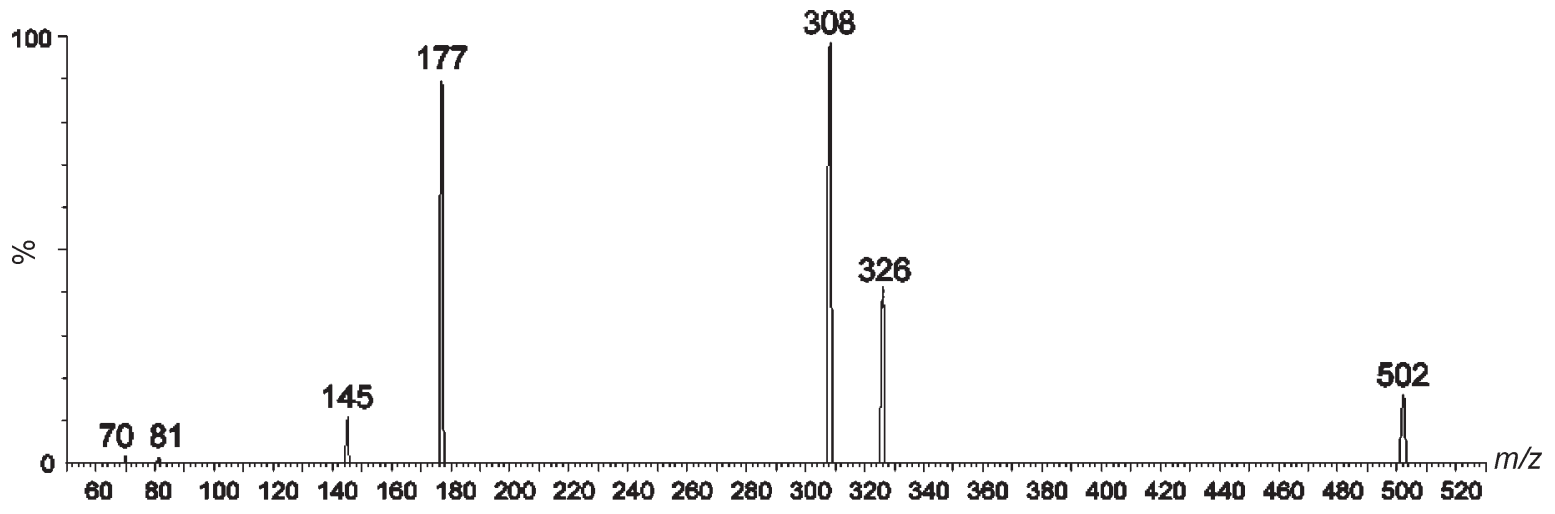

Figure 5. ESI-MS/MS of $\mathbf{1 3}$.

of $m / z, 298$ (pathway I) requires two different hydrogen shifts that do not involve the charged site. ${ }^{37}$ A literature search indicates that there are no previous reports for alkaloid $\mathbf{1 0 .}$

ESI-MS/MS of the ion of $m / z 474$ (12), shown in Figure 4, differ from that of $\mathbf{1 0}(\mathrm{m} / \mathrm{z} 444)$ only by the product ion of $\mathrm{m} / \mathrm{z}$. 177, which is $30 \mathrm{~m} / \mathrm{z}$ units heavier than that for $\mathbf{1 0}(\mathrm{m} / \mathrm{z}$ 147). This difference indicates an additional methoxyl group at the aromatic moiety, that is, a feruloyl group. ${ }^{23}$ Further evidence of a methoxyl group is given by the diagnostic ion of $m / z, 145$, formed by the loss of $\mathrm{CH}_{3} \mathrm{OH}$ from $\mathbf{E}$ (Table 1 ). In addition, other similarities between the spectra of $\mathbf{1 0}$ and 12 (i.e., the low mass fragment ion series of $\mathrm{m} / \mathrm{z}, 70,81,95$ and 109) are coherent with the proposed structure 12, which appears to be novel (Figure 1).

The ESI-MS/MS of the ion of $m / z 472$ (11) shows the fragment ions of $m / z 326$ and $m / z 308$ with a $28 \mathrm{~m} / z$ shift as compared to the corresponding ions of 10. However,

Table 2. Accurate mass measurements and formula assignments for 1-13

\begin{tabular}{|c|c|c|c|c|}
\hline Ion & Formula & Exact mass & Actual mass & Mass error (ppm) \\
\hline$[\mathbf{1}+\mathrm{H}]^{+}$ & $\mathrm{C}_{18} \mathrm{H}_{36} \mathrm{NO}_{2}^{+}$ & 298.2746 & 298.2758 & +4.0 \\
\hline$[2+\mathrm{H}]^{+}$or $[3+\mathrm{H}]^{+}$ & $\mathrm{C}_{20} \mathrm{H}_{40} \mathrm{NO}_{2}^{+}$ & 326.3059 & 326.3073 & +4.2 \\
\hline$[4+\mathrm{H}]^{+}$ & $\mathrm{C}_{18} \mathrm{H}_{36} \mathrm{NO}_{3}^{+}$ & 314.2695 & 314.2676 & -6.0 \\
\hline$[5+\mathrm{H}]^{+}$ & $\mathrm{C}_{20} \mathrm{H}_{40} \mathrm{NO}_{3}^{+}$ & 342.3008 & 342.2990 & -5.2 \\
\hline$[6+\mathrm{H}]^{+}$ & $\mathrm{C}_{20} \mathrm{H}_{38} \mathrm{NO}_{3}^{+}$ & 340.2852 & 340.2864 & +3.5 \\
\hline$[7+\mathrm{H}]^{+}$ & $\mathrm{C}_{22} \mathrm{H}_{42} \mathrm{NO}_{3}^{+}$ & 368.3165 & 368.3147 & -4.8 \\
\hline$[8+\mathrm{H}]^{+}$ & $\mathrm{C}_{18} \mathrm{H}_{38} \mathrm{NO}_{2}^{+}$ & 300.2903 & 300.2914 & +3.6 \\
\hline$[9+\mathrm{H}]^{+}$ & $\mathrm{C}_{20} \mathrm{H}_{42} \mathrm{NO}_{2}^{+}$ & 328.3216 & 328.3223 & +2.1 \\
\hline$[10+\mathrm{H}]^{+}$ & $\mathrm{C}_{27} \mathrm{H}_{42} \mathrm{NO}_{4}^{+}$ & 444.3114 & 444.3129 & +3.3 \\
\hline$[11+\mathrm{H}]^{+}$ & $\mathrm{C}_{29} \mathrm{H}_{46}^{+2} \mathrm{NO}_{4}^{+}$ & 472.3427 & 472.3412 & -3.1 \\
\hline$[12+\mathrm{H}]^{+}$ & $\mathrm{C}_{28} \mathrm{H}_{44} \mathrm{NO}_{5}^{+}$ & 474.3219 & 474.3198 & -4.4 \\
\hline$[13+\mathrm{H}]^{+}$ & $\mathrm{C}_{30} \mathrm{H}_{48} \mathrm{NO}_{5}^{+}$ & 502.3532 & 502.3511 & -4.1 \\
\hline
\end{tabular}


most of the fragment ions of $\mathbf{1 1}$ are the same as those of 10, including that of $\mathrm{m} / \mathrm{z} 147$, which is indicative of the $p$-coumaroyl group. These data strongly indicate that $\mathbf{1 1}$ differ from 10 only by two additional $\mathrm{CH}_{2}$ units at the side chain at $\mathrm{C}-3(\mathrm{n}=10$ for $\mathbf{1 1}$ instead of $\mathrm{n}=8$ for $\mathbf{1 0})$. In fact, comparison between ESI-MS/MS of $\mathbf{1 2}$ and $\mathbf{1 3}$ (Figure 4) reveals that $\mathbf{1 3}$ is similar to $\mathbf{1 2}$ differing only in the length of the side chain at C-6 $(\mathrm{n}=10)$. As for $\mathbf{1 0}$ and $\mathbf{1 2}$, there are no reports found for $\mathbf{1 1}$.

Aiming to confirm further the structures of all piperidine alkaloids, which were identified in this study, accurate-mass measurements were performed (Table 2). For 10-13, the fragment ions of $m / z, 145(\mathbf{1 0}, \mathbf{1 1})$ and $\mathrm{m} / \mathrm{z}$ $177(\mathbf{1 2}, \mathbf{1 3})$ corroborate the presence of a phenylpropanoid moiety (feruloyl or coumaroyl) at C-3 for these alkaloid co-metabolite series. All of the measured $\mathrm{m} / \mathrm{z}$ are in full agreement with those calculated for the proposed formula.

Analysis of S. spectabilis profile's from fruits and flowers extracts revealed a predominance of alkaloids with $\mathrm{n}=8$, unlike previous results, for which the compounds with $\mathrm{n}=10$ were the predominant. ${ }^{3}$ Our results also showed that the co-metabolites identified from flower extracts are more oxidized that those from fruits. The preferential accumulation of co-metabolites exhibiting different oxidation levels is likely to be associated with cellular differentiation in flowers tissues. We believe that this result could be of interest for further biosynthetic studies from this species.

There are, obviously, a number of structural features of the alkaloid skeleton that could not be assigned by mass spectrometry (i.e., configuration of the stereocenters at C2, C-3 and C-6). In the same manner, some minor product ions and mechanistic aspects of the ion fragmentation cannot be explained solely from ESI-MS/MS analysis. To fully elucidate the structures and to understand the ion fragmentation pathways, additional data from NMR and $\mathrm{MS}^{\mathrm{n}}$ are required. Nevertheless, this work demonstrated the usefulness of ESI-MS and ESI-MS/MS assisting on the preliminary but very fast and considerably reliable identification of novel and potentially bioactive cometabolite alkaloids from Senna species extracts.

\section{Acknowledgments}

This work was funded by grants of the State of São Paulo Research Foundation (FAPESP) within the BiotaFAPESP - The Biodiversity Virtual Institute Program (www.biotasp.org.br); Grant No. 03/02176-7 awarded to Dr. Bolzani, principal investigator. V. da S. B., I.C-G., and M. P, acknowledges CNPq, CAPES and FAPESP for fellowships.

\section{References}

1. Samy, R. P.; Ignacimuthu S.; Sen, A.; J. Ethnopharmacol. 1998, 62, 173.

2. Samy, R. P.; Ignacimuthu S.; J. Ethnopharmacol. 2000, $69,63$.

3. Viegas, Jr. C. Bolzani, V. S.; Furlan, M.; Barreiro, E. J.; Young, M. C. M.; Tomazela, D.; Eberlin, M. N.; J. Nat. Prod. 2004, 67, 908.

4. Moreira, M. S. A.; Viegas Jr., C.; Miranda, A. L. P.; Barreiro, E. J.; Bolzani, V. S.; Planta Med. 2003, 69, 795.

5. Bolzani, V. S.; Gunatilaka, A. A. L.; Kingston, D. G. I.; Tetrahedron 1995, 51, 5929.

6. Sriphong, L.; Sotanaphun, U.; Limsirichalkul, S.; Wetwitayaklung, P.; Chaichantipyuth, C.; Pummangura, S.; Planta Med. 2003, 69, 1054.

7. Mendez, A. M.; Phytochemistry 1971, 10, 2255.

8. Sansores-Peraza, P.; Rosado-Vallado, M.; Brito-Loeza, W.; Mena-Rejón, G. J.; Quijano, L.; Fitoterapia 2000, 71, 690.

9. Kamo, T.; Maehara, K.; Sato, K.; Hirota, M.; Heterocycles 2003, 60, 1303.

10. Albert, K.; Krucker, M.; Glaser, T.; Schefer, A.; Lienau, A.; Zeeb, D.; Anal. Bioanal. Chem. 2002, 372, 25.

11. Pinto, A. C.; Silva, D. H. S.; Bolzani, V. D.; Lopes, N. P.; Epifanio, R. D.; Quim. Nova 2002, 25 suppl. 1, 45.

12. Niessen, W. M. A.; Analusis 2000, 28, 885.

13. Fredenhagen, A.; Derrien, C.; Gassmann, E.; J. Nat. Prod. 2005, 68, 385.

14. Maurin, A. J. M.; Iamamoto, Y.; Lopes N. P.; Lindsay-Smith, J. R.; Bonato, P. S.; J. Braz. Chem. Soc. 2003, 14, 322.

15. Jung, W.; Yu, O.; Lau, S. M. C.; O'Keefe, D. P.; Odell, J.; Fader, G.; McGonigle, B.; Nature Biotech. 2000, 18, 208.

16. Jarvis, A. P.; Schaaf, O.; Oldham, N. J.; Planta 2000, 212, 119.

17. Hertweck, C.; Jarvis, A. P.; Xiang, L. K.; Moore, B. S.; Oldham, N. J.; Chem. Biochem. 2001, 2, 784.

18. Lange, B. M.; Ketchum, R. E. B.; Croteau, R. B.; Plant Physiol. 2001, 127, 305.

19. Kite, G. C.; Howes, M. J. R.; Simmonds, M. S. J.; Rapid Commun. Mass Spectrom. 2004, 18, 2859.

20. Hall, R.; Beale, M.; Fiehn, O.; Hardy, N.; Summer, L.; Bino, R.; Plant Cell 2002, 14, 1437.

21. Schobel, U.; Frenay, M.; Van Elswijk, V.; McAndrews, J. M.; Long, K. R.; Olson, L. M.; Bobzin, S. C.; Irth, H.; J. Biomol. Screen 2001, 6, 291.

22. Vuorela, P.; Leinonen, M.; Saikku, P.; Tammela, P.; Rauha, J. P.; Wennberg, T.; Vuorela, H.; Curr. Med. Chem. 2004, 11, 1375.

23. Lopes, N. P.; Stark, C. B. W.; Gates, P. J.; Staunton, J.; Analyst 2002, 127, 503.

24. Fonseca, T.; Lopes, N. P.; Gates, P. J.; Staunton, J.; J. Am. Soc. Mass Spectrom. 2004, 15, 325.

25. Lopes, N. P., Stark, C. B. W.; Hong, H.; Gates, P. J.; Staunton, J. Rapid Commun. Mass Spectrom. 2002, 16, 414. 
26. Crotti, A. E. M.; Lopes, J. L C.; Lopes, N. P.; J. Mass Spectrom. 2005, 40, 1030.

27. Gates, P. J.; Kearney, G. C.; Jones, R.; Leadlay, P. F.; Staunton, J.; Rapid Commun. Mass Spectrom. 1999, 13, 242.

28. Kearney, G. C.; Gates, P. J.; Leadlay, P. F.; Staunton, J.; Jones, R.; Rapid Commun. Mass Spectrom. 1999, 13, 1650.

29. Lopes, N. P.; Fonseca, T.; Wilkins, J. P. G.; Gates, P. J.; Chem. Commun. 2003, 1, 72.

30. Roddis, M.; Gates, P.; Roddis, Y.; Staunton, J.; J. Mass Spectrom. 2002, 13, 862.

31. Hong, H.; Gates, P. J.; Staunton, J.; Stinear, T.; Cole, S. T.; Leadlay, P. F.; Spencer, J. B.; Chem. Commun. 2003, 22, 2822.

32. McLafferty FW, Turecek F.; Interpretation of Mass Spectra, $4^{\text {th }}$ ed., University Science Books: Mill Valley, CA, 1993, p. 38.
33. Qin, X. Z.; J. Am. Soc. Mass Spectrom. 2002, 13, 371.

34. Highet, R. J.; J. Org. Chem. 1964, 29, 471.

35. Bily, A. C.; Burt, A. J.; Ramputh, A. I.; Livesey, J.; RegnaultRoger, C.; Philogène, B. R.; Arnason, J. T.; Phytochem. Anal. 2004, 15, 9 .

36. Dongré, A. R.; Jones, J. L.; Somogyi, A.; Wysocki, V. H.; J. Am. Chem. Soc. 1996, 118, 8365.

37. McLafferty FW, Turecek F.; Interpretation of Mass Spectra, $4^{\text {th }}$ ed., University Science Books: Mill Valley, CA, 1993, p. 80.

Received: May 24, 2005

Published on the web: December 5, 2005

FAPESP helped in meeting the publication costs of this article. 